\title{
Adult periodontitis - specific bacterial infection or chronic inflammation?
}

\begin{abstract}
Adult periodontitis, one of the major causes of tooth loss in adults, is a chronic, non-painful, inflammatory disease of the supporting tissues of the teeth. Its prevalence rivals that of the common cold, affecting $c$. $75 \%$ of the population in the USA [1]. Periodontitis is initiated and sustained by a local gram-negative bacterial infection under the gum-line, commonly called plaque. Recent studies now support a role for adult periodontitis in contributing to more serious conditions than tooth loss, such as cardiovascular disease [2], pre-term labour, and low-birth-weight babies [3]. The highly vascular nature of the tissues surrounding the teeth (the periodontium), combined with the presence of $10^{8}-10^{9} \mathrm{cfu}$ of bacteria $/ \mathrm{mg}$ of plaque mass [4], has generated speculation that low level endotoxaemia and systemic cytokine release are responsible for the systemic manifestations of the disease [3]. Therefore, a better understanding of the mechanisms involved in the pathogenesis of adult periodontitis is important in understanding chronic infectious and inflammatory diseases in general.
\end{abstract}

The crevice between the teeth and gingiva provides an ecological niche for several hundred different bacterial taxa [5], however, only about 8-12 species have been implicated in the aetiology of periodontitis (for a review, see reference [6]). Of these, the gram-negative anaerobe Porphyromonas gingivalis is often used as the model for investigation of the pathogenesis of periodontitis; $P$. gingivalis is usually cultured in high numbers from the gingival crevice of patients with periodontitis [6] and the disease can be induced in non-human primates by monoinfecting them with the organism [7]. People with periodontitis often have an increased IgG antibody titre [8] and avidity [9]; however, the antibody response is predominantly IgG2 subclass [10], and is not opsonic for $P$. gingivalis. Antibody specific for complement C3degrading proteinases is apparently required for optimum opsonisation of $P$. gingivalis in vitro [11].

The potential virulence factors produced by $P$. gingivalis [12] include a unique lipopolysaccharide (LPS) moiety that can bind and sequester the essential growth factor haemin in vitro [13]. This LPS also induces the production of pro-inflammatory cytokines by human neutrophils, monocytes, macrophages and fibroblasts $[14,15]$. Paradoxically, the release of interleukin-1 (IL-1) receptor antagonist and interferon- $\gamma$ (IFN- $\gamma$ ), which should down-regulate inflammation, are also stimulated by $P$. gingivalis LPS. Moreover, E-selectin expression on human endothelial cells is inhibited by $P$. gingivalis LPS [16]. Other important virulence factors include: fimbriae that mediate the colonisation of the tooth and epithelial cell surface by $P$. gingivalis [17]; an anti-phagocytic capsule [18, 19]; invasins [20]; and potent proteinases that degrade complement $\mathrm{C} 3$, IgG [11] and receptors on leucocytes for complement C5a [21]. Non-LPS components like lipid A-associated proteins, capsular polysaccharide, fimbrial proteins and various unidentified proteins can also stimulate pro-inflammatory cytokine release from different cell types [14].

Although the initiation of periodontitis requires the accumulation of specific plaque bacteria such as $P$. gingivalis, differences in the incidence and severity of disease in adults are not accounted for by the quantity and type of bacteria in the gingival crevice. $P$. gingivalis and other putative pathogens do not qualify as aetiological agents for several reasons: (1) in several studies of the microflora of adult periodontitis, up to $30 \%$ of patients had no detectable levels of $P$. gingivalis [22]; (2) P. gingivalis is readily transmitted between cohabiting family members, who do not apparently contract periodontitis [23]; (3) restriction fragment length polymorphism studies and multilocus enzyme electrophoresis analysis of genetic structures of natural populations of $P$. gingivalis suggest a relatively benign commensal species, or an opportunist [24]; (4) levels of $P$. gingivalis do not correlate with clinical measures of periodontitis activity [25]; (5) a monoinfection is necessary in order to induce periodontitis in vivo, and this does not exist in the oral cavity in nature.

Efforts are under way to develop a biofilm model of bacterial plaque [26]. Alternatively, a well-defined 'cocktail' of bacterial antigens, such as LPS, fimbrillin, proteinases and capsular polysaccharide may better mimic the diversity of molecules encountered by myeloid and non-myeloid cells in the periodontium.

A paradigm shift is apparently occurring in periodontal research, from study of the destruction of host tissue directly by specific bacteria and their antigens, to study of the pro-inflammatory response to these antigens [14]. Whereas enhancement of the immune response was the former therapeutic goal [11, 27], the present emphasis is on controlling the damage caused by the proinflammatory response. Biochemical markers or risk factors known to predict the severity of periodontitis include prostaglandin E2 [28], and the specific genotype of the polymorphic IL-1 gene cluster [29]. It has been 
suggested that the cells from subjects positive for the IL-1 genotype produce more IL-1b in response to infectious challenge (LPS), and these subjects thus get more severe periodontitis than those of other genotypes [29]. There is good evidence for the involvement of various pro-inflammatory cytokines in the pathology of periodontitis. Increased levels of IL-1, tumour necrosis factor- $\alpha$ and IL- 6 are found in the gingival crevice in periodontitis $[30,14]$. These cytokines are found both as the protein and mRNA transcripts in the inflamed gingival tissue [31]. Other cytokines and chemokines, including IL-4, IL-5, IFN- $\gamma$, TGF- $\beta$ and IL-8 have also been found in inflamed gingiva $[32,33]$.

Very little is understood of the temporal nature of the proinflammatory response to the plaque biofilm during the progression from health to gingivitis to periodontitis. Even less is known of the specific role of cytokines, glucocorticoids and growth factors released by myeloid and non-myeloid cells during active gingivitis and periodontitis. These studies are critical to the development of therapeutic strategies for the prevention and treatment of periodontitis and other chronic inflammatory diseases.

R. JOTWANI AND C. W. CUTLER* Department of Periodontics and Biomedical Sciences, Baylor College of Dentistry, Texas A \& M University System, 3302 Gaston Ave, Dallas, Texas 75246, USA E-mail: cwcutler@ont.com

${ }^{*}$ Corresponding author.

\section{References}

1. Brown LJ, Oliver RC, Loe H. Periodontal diseases in the U.S. in 1981; prevalence, severity, extent, and role in tooth mortality. J Periodontol 1989; 60: 363-370.

2. DeStafano F, Anda RF, Kahn HS, Williamson DF, Russell CM. Dental disease and risk of coronary heart disease and mortality. BMJ 1993; 306: 688-691.

3. Beck J, Garcia R, Heiss G, Vokonas PS, Offenbacher S. Periodontal disease and cardiovascular disease. $J$ Periodontol 1996; 67:(10 Suppl) 1123-1137.

4. Socransky SS, Gibbons RJ, Dale AC, Bortnick L, Rosenthal E, Macdonald JB. The microbiota of the gingival crevice of man. I. Total microscopic and viable counts and counts of specific microorganisms. Arch Oral Biol 1963; 8: 275-280.

5. Moore WEC, Moore LVH. The bacteria of periodontal diseases. Periodontol 2000 1994; 5: 66-77.

6. Dzink JL, Socransky SS, Haffajee AD. The predominant cultivable microbiota of active and inactive lesions of destructive periodontal diseases. J Clin Periodontol 1988; 15: 316-323.

7. Holt SC, Ebersole J, Felton J, Brunsvold M, Kornman KS. Implantation of Bacteroides gingivitis in nonhuman primates initiates progression of periodontitis. Science 1988; 239: 55-57.

8. Cutler CW, Kalmer JR, Arnold RR. Antibody-dependent alternate pathway of complement activation in opsonophagocytosis of Porphyromonas gingivalis. Infect Immun 1991; 59: 2105-2109.

9. Benjamin PA, Rogers PA, Johnson NW, Cole MF, Curtis MA Increased titre and avidity of IgG antibodies to Porphyromonas gingivalis whole cells and a cell surface protein in subjects with adult periodontitis. J Periodont Res 1997; 32: 31-39.

10. Katz J, Leary RM, Ward DC, Harmon CC, Michalek M. Humoral response to Porphyromonas (Bacteroides) gingivalis in rats: time course and T-cell dependence. Infect Immun 1992; 60: $3579-3585$.

11. Cutler CW, Arnold RR, Schenkein HA. Inhibition of C3 and
IgG proteolysis enhances phagocytosis of Porphyromonas gingivalis. J Immunol 1993; 151: 7016-7029.

12. Cutler CW, Kalmar JR, Genco CA. Pathogenic strategies of the oral anaerobe, Porphyromonas gingivalis. Trends Microbiol $1995 ; 3: 45-50$.

13. Cutler CW, Eke PI, Genco CA, Van Dyke TE, Arnold RR Hemin-induced modifications of the antigenicity and heminbinding capacity of Porphyromonas gingivalis lipopolysaccharide. Infect Immun 1996; 64: 2282-2287.

14. Wilson M, Reddi K, Henderson B. Cytokine-inducing components of periodontopathogenic bacteria. J Periodont Res 1996 31: 393-407.

15. Yoshimura A, Hara Y, Kaneko T, Kato I. Secretion of IL-1 beta, TNF-alpha, IL-8 and IL-1ra by human polymorphonuclear leukocytes in response to lipopolysaccharides from periodontopathic bacteria. J Periodont Res 1997; 32: 279-286.

16. Cunningham MD, Seachord C, Ratcliffe K, Brainbridge B, Aruffo A, Darveau RP. Helicobacter pylori and Porphyromonas gingivalis lipopolysaccharides are poorly transferred to recombinant soluble CD14. Infect Immun 1996; 64: 3601-3608.

17. Loos BG, Dyer DW. Restriction fragment length polymorphism analysis of the fimbrillin locus, film A, of Porphyromonas gingivalis. J Dent Res 1992; 71: 1173-1181.

18. Sundqvist G, Figdor D, Hanstrom L, Sorlin S, Sandstrom G. Phagocytosis and virulence of different strains of Porphyromonas gingivalis. Scand J Dent Res 1991; 99: 117-129.

19. Genco CA, Schifferle RE, Njoroge T, Forng R-Y, Cutler CW Resistance of a Tn4351-generated polysaccharide mutant of Porphyromonas gingivalis to polymorphonuclear leukocyte killing. Infect Immun 1995; 63: 393-401.

20. Duncan MJ, Nakao S, Skobe $Z$, Xie $H$. Interaction of Porphyromonas gingivalis with epithelial cells. Infect Immun 1993; 61: 2260-2265.

21. Jagels MA, Ember JA, Travis J, Potempa J, Pike R, Hugli TE. Cleavage of the human $\mathrm{C} 5 \mathrm{a}$ receptor by proteinases derived from Porphyromonas gingivalis: cleavage of leukocyte C5a receptor. Adv Exp Med Biol 1996; 389: 155-164.

22. Moore WEC, Holdeman LV, Smibert RM, Hash DE, Burmeister JA, Ranney RR. Bacteriology of severe periodontitis in young adult humans. Infect Immun 1982; 38: 1137-1148.

23. Petit MD, van-Steenbergen TJ, Scholte LM, van-der-Velden U, de Graaff J. Epidemiology and transmission of Porphyromonas gingivalis and Actinobacillus actinomycetemcomitans among children and their family members. A report of 4 surveys. $J$ Clin Periodontol 1993; 20: 641-650.

24. Loos BG, Dyer DW, Whittam TS, Selander RK. Genetic structure of populations of Porphyromonas gingivalis associated with periodontitis and other oral infections. Infect Immun 1993; 61: $204-212$.

25. Rams TE, Listgarten MA, Slots J. Utility of 5 major putative periodontal pathogens and selected clinical parameters to predict periodontal breakdown in patients on maintenance care. $J$ Clin Periodontol 1996; 23: 346-354.

26. Kinniment SL, Wimpenny JW, Adams D, March PD. The effect of chlorhexidine on defined, mixed culture oral biofilms grown in a novel model system. $J$ Appl Bacteriol 1996; 81: $120-125$

27. Hart TC, Shapira L, Van-Dyke TE. Neutrophil defects as risk factors for periodontal diseases. J Periodontol 1994; 65: (5 Suppl) 521-529.

28. Offenbacher S, Heasman PA, Collins JG. Modulation of host PGE-2 secretion as determinant of periodontal disease expression. J Periodontol 1993; 64: (5 Suppl) 432-444.

29. Kornman KS, Crane A, Wang H-Y et al. The interleukin-1 genotype as a severity factor in adult periodontal disease. $J$ Clin Periodontol 1997; 24: 72-77.

30. Reinhardt RA, Masada MP, Kaldahl WB et al. Gingival fluid IL-1 and IL-6 levels in refractory periodontitis. $J$ Clin Periodontol 1993; 20: 225-231.

31. Matsuki Y, Yamamoto T, Hara K. Localization of interleukin-1 (IL-1) mRNA-expressing macrophages in human inflamed gingiva and IL-1 activity in gingival crevicular fluid. $J$ Peridont Res 1993; 28: 35-42.

32. Kjeldsen M, Holmstrup P, Bendtzen K. Marginal periodontitis and cytokines: a review of the literature. J Periodontol 1993; 64: $1013-1022$.

33. Okada N, Kobayashi M, Mugikura $\mathrm{K}$ et al. Interleukin-6 production in human fibroblasts derived from periodontal tissues is differentially regulated by cytokines and a glucocorticoid. J Periodontol Res 1997; 32: 559-569. 